\title{
rRNA sequences reflect the ecophysiology and define the toxic cyanobacteria of the genus Nodularia
}

\author{
Michelle C. Moffitt, ${ }^{1}$ Susan I. Blackburn ${ }^{2}$ and Brett A. Neilan ${ }^{1}$ \\ Author for correspondence: Brett A. Neilan. Tel: +612 9385 3235. Fax: +612 93851591. \\ e-mail: b.neilan@unsw.edu.au
}

\footnotetext{
1 School of Microbiology and Immunology, The University of New South Wales, Sydney, NSW 2052, Australia

2 CSIRO Division of Marine Research, GPO Box 1538, Hobart, Tasmania 7001, Australia
}

\begin{abstract}
Nodularia, a member of the order Nostocales, is a bloom-forming filamentous cyanobacterium that possesses the ability to form toxic blooms. The toxin produced by Nodularia, nodularin, is a hepatotoxin, similar in structure to the heptapeptide toxin microcystin. Twenty-one strains of Nodularia, representing the species Nodularia spumigena, Nodularia harveyana and Nodularia sphaerocarpa, were analysed for toxin production by protein phosphatase inhibition assay and sequenced over the 165 rDNA region. Phylogenetic analysis of Nodularia 16S rDNA sequences found that Nodularia clustered into two main groups. An N. spumigena cluster was distinct from the benthic species $\boldsymbol{N}$. harveyana and $\boldsymbol{N}$. sphaerocarpa. There was no distinction between strains isolated from globally diverse locations. Nodularin-producing species were restricted to the single, evolutionally distinct cluster of $\boldsymbol{N}$. spumigena. This observation has enabled the design of a specific 16S rRNA PCR for the rapid detection of nodularin-producing strains. Alignment of 165 rDNA sequences from toxic and non-toxic Nodularia with other members of the cyanobacteria allowed the design of both Nodularia generic and toxic $N$. spumigena-specific primers.
\end{abstract}

Keywords: Nodularia, cyanobacteria, 16S rRNA, nodularin, evolution

\section{Introduction}

The cyanobacteria phylum is one of the 11 traditional phyla of the Bacteria (Schleifer \& Ludwig, 1989; Woese, 1987). A number of cyanobacteria are of interest due to their bloom-forming potential and their ability to produce a wide range of secondary metabolites (Carmichael et al., 1988; Patterson et al., 1994). Currently, the genus Nodularia is defined taxonomically by its morphological characters and ecological requirements (Komàrek et al., 1993). Nodularia is a bloom-forming filamentous cyanobacterium, placed within the order Nostocales and family Nostocaceae (Komàrek et al., 1993; Nordin \& Stein, 1980; Rippka et al., 1979).

Species within the genus Nodularia are classified by a combination of morphological features and the ecological niche from which they are isolated (Komàrek et al., 1993). Historically, the classification of species

Abbreviations: IGS, intergenic spacer; PP-2A, protein phosphatase $2 \mathrm{~A}$; RAPD, randomly amplified polymorphic DNA. within the genus Nodularia has been controversial. Recently, the genus was revised by Komàrek et al. (1993) to yield seven taxa. Taxonomically, the production of gas vesicles divides the Nodularia genus into two main groups: the benthic or terrestrial species Nodularia harveyana, Nodularia sphaerocarpa and Nodularia willeii; and the planktonic species Nodularia spumigena, Nodularia baltica, Nodularia litorea and Nodularia crassa (Komàrek et al., 1993).

Traditionally, cyanobacteria are identified according to their morphology, but due to several and variable morphotypes and the problems associated with laboratory culturing, the use of molecular techniques for cyanobacterial identification is now in common use. In the past, phylogenetic studies of Nodularia using $16 \mathrm{~S}$ rRNA sequence analysis has been limited (Lehtimäki et al., 1994; Barker et al., 1999). However, a study of the 16S rDNA sequences of three Baltic Sea Nodularia isolates found each to be identical (Barker et al., 1999). Phylogenetic studies of $N$. spumigena strains have been performed using the DNA sequence or RFLPs of the phycocyanin intergenic spacer (IGS) region and 
randomly amplified polymorphic DNA (RAPD)-PCR (Bolch et al., 1996, 1999; Hayes \& Barker, 1997; Neilan et al., 1995). DNA sequencing of the $c p c$-IGS and analysis of $c p c$-IGS RFLP fragments from Baltic, Canadian and Australian Nodularia isolates by Hayes \& Barker (1997) suggested that Nodularia genotypes may have a global distribution. Consecutive studies by Bolch et al. $(1996,1999)$ reviewed the Nodularia taxonomy by $c p c$-IGS RFLPs, sequencing and RAPDPCR and compared these results to toxicity and morphology (Bolch et al., 1999). Results indicated that overseas strains were genetically distinct from Australian strains, refuting the argument by Hayes \& Barker (1997) that Nodularia genotypes are globally distributed. These conflicting studies supported the need for further study into Nodularia phylogeny and evolution.

Blooms of Nodularia are common within the estuaries and coastal lagoons of Australia (Jones et al., 1994; Heresztyn \& Nicholson, 1997), occur annually during summer months in the Baltic Sea (Sivonen et al., 1989) and have been reported in the German North Sea coast (Nehring, 1993), New Zealand (Carmichael et al., 1988) and North America (Galat et al., 1990). Many Nodularia blooms are highly toxic due to their production of the cyclic pentapeptide hepatotoxin nodularin. The consumption of water-containing toxic Nodularia blooms has led to the death of domestic and native animals by massive liver haemorrhage in Australia, the Baltic Sea and New Zealand (Carmichael et al., 1988; Francis, 1878; Nehring, 1993; Carmichael, 1994). In subacute doses, nodularin may act as a liver tumour promoter and initiator (Ohta et al., 1994). For these reasons, rapid and accurate identification of toxic Nodularia in cyanobacterial bloom events is important.

In the present study, several strains of $N$. spumigena, $N$. harveyana and $N$. sphaerocarpa, isolated from geographically diverse regions, were analysed for the production of toxin and sequenced over the 16S rRNA gene region to determine if the current Nodularia morphological taxonomy is supported by $16 \mathrm{~S}$ rRNA phylogeny. It was also an aim of this work to confirm or refute the proposed globality of Nodularia species distribution based on the sequence of 16S rDNA, an evolutionally significant character. These sequence data were also used to design PCR primers for the specific detection of toxic-bloom-forming strains of the genus Nodularia and for the identification of morphologically ambiguous strains from culturable and non-culturable environmental isolates.

\section{Methods}

Bacterial strains. Cyanobacterial strains used in this study (Table 1) were provided by the CSIRO Marine Laboratories (Hobart, Tasmania), Department of Applied Chemistry and Microbiology (University of Helsinki, Finland) and the Department of Biological Sciences (Wright State University, Dayton, $\mathrm{OH}, \mathrm{USA})$. Other strains were also obtained from Pasteur Culture Collection (PCC), the Culture Collection of
Algae at the University of Texas (UTEX) and the Czechoslovak Database of Algae and Cyanobacteria (CDAC). Cultures were maintained in BG- 11 media at $25^{\circ} \mathrm{C}$ with an illuminance of $1500 \mathrm{~lx}$. All cell cultures were uni-algal. Heterotrophic bacteria were removed by filtering of cyanobacterial cultures through a $3 \cdot 0 \mu \mathrm{m}$ SS type MF-Millipore filter and washing with sterile milli-Q water.

Measurement of toxicity. Bioassay for nodularin content was performed using a protein phosphatase 2A (PP-2A) inhibition assay as previously described by An \& Carmichael (1994). Toxin was liberated from cells by three freeze-thaw cycles. The sample was then incubated with PP-2A enzyme at $37^{\circ} \mathrm{C}$ for $80 \mathrm{~min}$. The toxicity of the sample was determined by assaying the inability of the PP-2A to convert the substrate $p$-nitrophenol phosphate to nitrophenol phosphate. The relative concentration of nodularin was determined from a standard curve of inhibition of PP-2A by given concentrations of microcystin.

DNA isolation, amplification and sequencing. Total genomic DNA was extracted using an SDS/lysozyme-based method as previously described by Neilan et al. (1995). Cells were incubated with $0.5 \mathrm{ml}$ TNE buffer [ $50 \mathrm{mM}$ Tris $(\mathrm{pH} 8.0)$, $5 \mathrm{mM}$ EDTA (pH 8.0), $50 \mathrm{mM} \mathrm{NaCl}$ and lysozyme (Pharmacia) at a final concentration of $1 \mathrm{mg} \mathrm{ml}^{-1}$ for $30 \mathrm{~min}$ at $55^{\circ} \mathrm{C}$. This was followed by the addition of $10 \mu \mathrm{l} 20 \%$ SDS and $10 \mu \mathrm{l}$ proteinase $\mathrm{K}\left(10 \mathrm{mg} \mathrm{ml}^{-1}\right)$ (Promega) and incubated for a further $10 \mathrm{~min}$ at $55^{\circ} \mathrm{C}$. DNA was then extracted with an equal volume of phenol/chloroform/ isoamyl alcohol $(25: 24: 1)$ and precipitated from the supernatant by the addition of 1 vol. $4 \mathrm{M}$ ammonium acetate and 1 vol. 2-propanol.

All PCR reactions were performed using 1 unit Taq polymerase (Fischer Biotech) in a $30 \mu \mathrm{l}$ reaction mix containing $2.5 \mathrm{mM} \mathrm{MgCl}, 1 \times$ Taq polymerase buffer (Fischer Biotech), 0.2 mM dNTPs (Boehringer Mannheim), $0.2 \mathrm{pM}$ forward and reverse primer and $1 \mathrm{ng}$ DNA template. The final volume was adjusted with sterile milli-Q water. Thermal cycling was performed in a PCR Sprint Temperature Cycling System machine (Hybaid) or a GeneAmp PCR System 2400 Thermocycler (Perkin Elmer). Amplification of the nearcomplete 16S rRNA gene was performed by PCR using oligonucleotide primers and conditions described by Neilan et al. (1997). The initial denaturation step at $94{ }^{\circ} \mathrm{C}$ for $5 \mathrm{~min}$ was followed by 30 cycles of DNA denaturation at $94{ }^{\circ} \mathrm{C}$ for $5 \mathrm{~s}$, primer annealing at $55^{\circ} \mathrm{C}$ for $10 \mathrm{~s}$, strand extension at $72^{\circ} \mathrm{C}$ for $45 \mathrm{~s}$ and a final extension step at $72^{\circ} \mathrm{C}$ for $7 \mathrm{~min}$. Amplification using the toxic Nodularia-specific primer, NTS [TGTGATGCAAATCTCA(C/A)A] and universal 16S rRNA reverse primer 1494R (Neilan et al., 1997) was performed with thermal cycling conditions as above, with a primer annealing temperature of $63{ }^{\circ} \mathrm{C}$. Amplification using the Nodularia generic primer, NS2 (GGCGAAGGCGCTCTACTA) and universal 16S rRNA reverse primer 1494R (Neilan et al., 1997) was performed in a two-step thermal cycling procedure with an initial denaturation step of $94^{\circ} \mathrm{C}$ for $5 \mathrm{~min}, 30$ cycles of DNA denaturation at $94{ }^{\circ} \mathrm{C}$ for $5 \mathrm{~s}$, primer annealing and strand extension at $69^{\circ} \mathrm{C}$ for $45 \mathrm{~s}$, and a final extension step at $72{ }^{\circ} \mathrm{C}$ for $7 \mathrm{~min}$.

Automated DNA sequencing was performed using the PRISM Big Dye cycle sequencing system and a model 373 sequencer (Applied Biosystems). Oligonucleotide primers were synthesized using a model 8000 DNA synthesis system (Beckman).

All Nodularia 16S rDNA sequences were checked for ambiguities using the CHIMERA detection program in the 
Table 1 Cyanobacterial strains used in this study and their ability to produce nodularin as determined by protein phosphatase inhibition assay

\begin{tabular}{|c|c|c|c|c|c|c|c|}
\hline Species* & Strain & Co-identity & Site of isolation & Isolation & $\begin{array}{c}\text { Nodularin } \\
\text { prodn } \dagger\end{array}$ & Reference & $\begin{array}{l}\text { Accession } \\
\text { no. }\end{array}$ \\
\hline N. spumigena & NSBL05 & & Lake Bullenmeri, VIC, Australia & S. Blackburn, 1993 & - & & AF268012 \\
\hline N. spumigena & NSBR01 & & Blackwood River, WA, Australia & T. Pitman, 1994 & + & & AF268016 \\
\hline N. spumigena & NSGL02A10 & & Gipsland Lakes, VIC, Australia & C. Bolch, 1993 & + & Bolch et al. (1999) & AF268015 \\
\hline N. spumigena & NSKR07 & & Kaljon River, WA, Australia & T. Pitman, 1995 & + & & AF268013 \\
\hline N. spumigena & NSLA01 & & Lake Alexandrina, SA, Australia & P. Baker, 1990 & + & Bolch et al. (1999) & AF268009 \\
\hline N. spumigena & NSLA02A4 & & Lake Alexandrina, SA, Australia & T. Pitman, 1994 & + & & AF268008 \\
\hline N. spumigena & NSOR04 & & Orielton Lagoon, TAS, Australia & C. Bolch, 1993 & + & Bolch et al. (1999) & AF268010 \\
\hline N. spumigena & NSOR 10 & & Orielton Lagoon, TAS, Australia & S. Blackburn, 1993 & + & & AF268014 \\
\hline N. spumigena & NSOR 12 & & Orielton Lagoon, TAS, Australia & S. Blackburn & + & & AF268011 \\
\hline N. spumigena & NSPH02 & & Peel Inlet, WA, Australia & S. Blackburn, 1992 & + & & AF268007 \\
\hline N. spumigena & NSPH05A14 & & Peel Inlet, WA, Australia & T. Pitman, 1994 & + & & AF268017 \\
\hline N. spumigena & L575 & & Lake Ellesmere, New Zealand & W. Carmichael, 1980 & $+t$ & Carmichael et al. (1988) & AF268006 \\
\hline N. spumigena & BY1 & & Baltic Sea & K. Sivonen & + & Lehtimäki et al. (1994) & AF268004 \\
\hline N. spumigena & HEM & & Baltic Sea & K. Sivonen & + & Lehtimäki et al. (1994) & AF268005 \\
\hline $\begin{array}{l}\text { N. spumigena/ } \\
\text { N. sphaerocarpa }\end{array}$ & HKVV & & Baltic Sea & K. Sivonen & - & Lehtimäki et al. (1994) & AF268024 \\
\hline N. spumigena & PCC $73104^{\mathrm{T}}$ & $\begin{array}{c}\text { UTEX-B2091 }{ }^{\mathrm{T}}, \\
\text { ATCC } 29167^{\mathrm{T}}, \\
\text { CCAP- } 1452 / 4^{\mathrm{T}}\end{array}$ & $\begin{array}{l}\text { Alkaline soil, Spotted Lake, } \\
\text { BC, Canada }\end{array}$ & R. Rippka, 1979 & - & Rippka et al. (1992) & AF268023 \\
\hline$N$. harveyana & PCC 7804 & & Thermal Spring, Dax, France & R. Pourriot, 1966 & + & Rippka et al. (1992) & AF268019 \\
\hline N. spumigena & UTEX-B2092 & & Alkaline soil, Osoyoos, BC, Canada & J. Stein, 1974 & - & & AF268022 \\
\hline$N$. harveyana & UTEX-B2093 & PCC 9336 & $\begin{array}{l}\text { Pond, San de Fuca, Whidbey Island, } \\
\text { WA, USA }\end{array}$ & & - & $\begin{array}{l}\text { Nordin \& Stein (1980); } \\
\text { Rippka et al. (1992) }\end{array}$ & AF268021 \\
\hline$N$. harveyana & CDAC1983/300 & & $\begin{array}{l}\text { Island Hiddensee, Lagoon-Gellen, } \\
\text { Germany }\end{array}$ & Habel, 1983 & - & Komàrek et al. (1993) & AF268020 \\
\hline N. sphaerocarpa & CDAC1966/93-1 & & Thermal Spring, Dax, France & R. Pourriot, 1966 & - & Komàrek et al. (1993) & AF268018 \\
\hline Anabaena sp. & PCC 7210 & & Unknown & R. Haselkorn & ND & Ligon et al. (1991) & X59559 \\
\hline $\begin{array}{l}\text { Anabaena } \\
\text { cylindrica }\end{array}$ & NIES19 & & England & & ND & & \\
\hline Cylindrospermopsis & AWT205 & & Ornamental Pond, NSW, Australia & & ND & Hawkins et al. (1997) & \\
\hline Lyngbya & AWT211 & & Unknown & & ND & & \\
\hline Aphanizomenon & NIES81 & & Lake Kasumigaura, Japan & & ND & & \\
\hline Synechocystis & PCC 6803 & & Fresh water, CA, USA & R. Kunisawa, 1968 & ND & Rippka et al. (1979) & \\
\hline $\begin{array}{l}\text { Microcystis } \\
\text { aeruginosa }\end{array}$ & PCC 7806 & & Braakman Reservoir, The Netherlands & R. Rippka, 1972 & ND & Rippka et al. (1992) & \\
\hline
\end{tabular}

* Nodularia strains listed were sequenced over the 16S rDNA region. The Anabaena strain was used in the phylogenetic analysis. All other cyanobacterial genera listed were used to determine the specificity of Nodularia $16 \mathrm{~S}$ rRNA oligonucleotide primers.

$\dagger+$ or - indicates the presence or absence of toxin as determined by PP-2A inhibition assay. ND, Not determined.

워 \$L575 culture was unavailable for toxicity assay; however, it has been shown to produce nodularin (Carmichael et al., 1988). 
Ribosomal Database Project II (http:/ /www.cme.msu.edu/ $\mathrm{RDP} /$ cgis/chimera.cgi).

Phylogenetic analyses. All 16S rRNA gene sequences used in this study were aligned using the programs PILEUP from GCG and the multiple-sequence alignment tool from CLUSTAL W (Thompson et al., 1994). Manual alignment of the output was also performed with consideration for the secondary structure of the $16 \mathrm{~S}$ rRNA molecule. The input order of taxa was randomized for all sequence alignments and phylogenetic inference programs. Genetic distances $(D)$ between strains were calculated using the formula described by Jukes \& Cantor (1969), $D=-\frac{3}{4} \ln \left(1-\frac{4}{3} d\right)$, where $d$ is the level of sequence dissimilarity. The phylogenetic inference protocols DNADIST, NEIGHBOR, SEQBOOT and CONSENSE were supplied by the PHYLIP package (version 3.57c) (Felsenstein, 1985). Sequence manipulation and phylogeny programs were accessed through the Australian National Genome Information Service (Sydney, Australia).

\section{RESULTS AND DISCUSSION}

\section{Phylogenetic analysis of Nodularia 16S rDNA sequences}

Near-complete sequences from position 27F to 1494R of the 16S rRNA gene were generated for 21 strains of Nodularia during this study (Table 1). All Nodularia strains sequenced were most similar, by BLAST analysis, to the Nodularia strain BCNOD9427 16S rRNA gene sequence (accession no. AJ224447) in the EMBL database (similarity 96-99\%).

The current morphological taxonomy of Nodularia describes the genus as being composed of seven species (Komàrek et al., 1993). This phylogenetic study concentrated on three main species, i.e. those which were available for molecular investigations. A phylogenetic distance tree (Fig. 1) was obtained from the alignment of Nodularia sequences with Nodularia sp. BCNOD9427 and Anabaena PCC $7120^{\mathrm{T}}$, the type strain from a closely related genus of the order Nostocales used as an outgroup. Evolutionary relationships (Fig. 1) and genetic distances were determined by the alignment of $1322 \mathrm{bp}$ from within the 16S rRNA gene sequence. Parsimony and maximum-likelihood analysis confirmed the tree topology presented is the most probable.

Strains of $N$. spumigena isolated from blooms in Australia, New Zealand and the Baltic Sea clustered together as one group. This N. spumigena group could further be separated into two subgroups: one containing Australian strains only; and the other group containing strains from the Baltic Sea, New Zealand and from Lake Alexandrina in Australia. N. harveyana and $N$. sphaerocarpa are morphologically distinct from $N$. spumigena due to their inability to produce gas vesicles. $N$. harveyana and $N$. sphaerocarpa strains were phylogenetically distinct from the $N$. spumigena clade (Fig. 1). This benthic group may be polyphyletic, although delineation of the benthic strains into the species $N$. harveyana and $N$. sphaerocarpa was not possible due to the lack of strains representative of these species available for this study. Future analysis

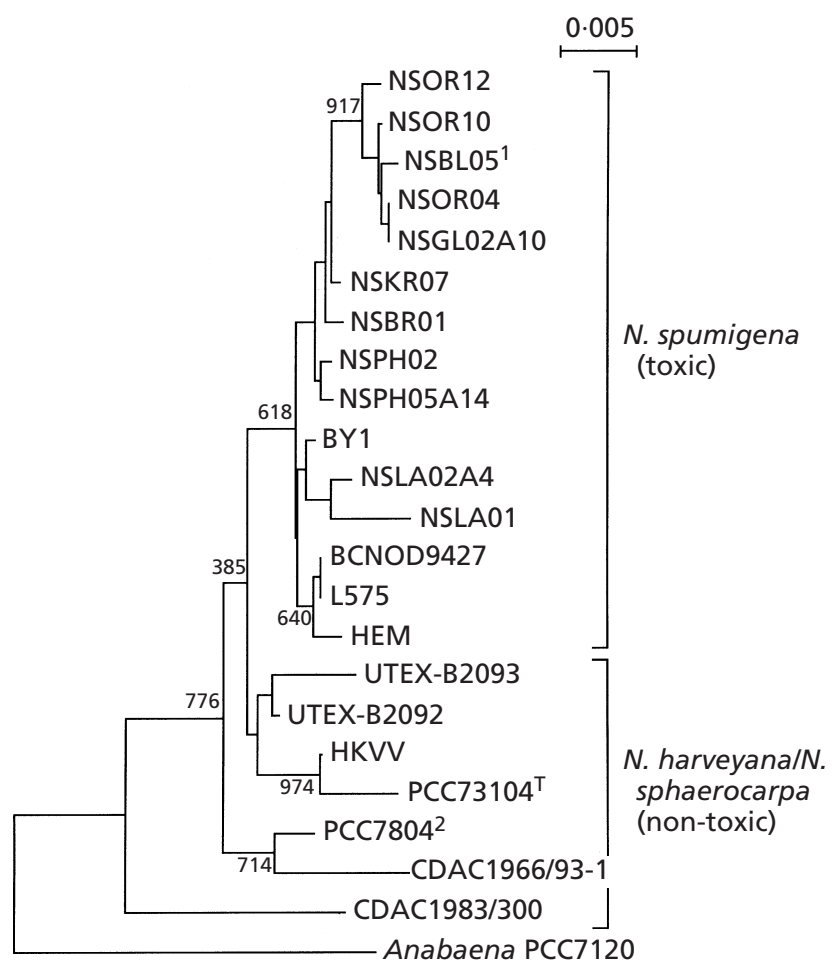

Fig. 1. Phylogenetic representation of the genus Nodularia based on the alignment of 1322 bases within the 16S rRNA gene sequences used. Genetic distances $(D)$ between strains were calculated using the formula described by Jukes \& Cantor (1969), $D=-\frac{3}{4} \ln \left(1-\frac{4}{3} d\right)$, where $d$ is the level of sequence dissimilarity. The phylogenetic inference protocols DNADIST, NEIGHBOR, SEQBOOT and CONSENSE were supplied by the PHYLIP package (version 3.57c) (Felsenstein, 1985). Scale bar, 5 base substitution per 1000 nucleotides. Significant bootstrap values (Felsenstein, 1985) calculated from 1000 bootstrap trees are indicated at the nodes. ${ }^{1} N$. spumigena NSBL05 appeared nontoxic by the PP-2A assay. ${ }^{2} \mathrm{~N}$. harveyana PCC 7804 appeared toxic by the PP-2A assay.

of these groups should be performed to determine the correct speciation of the benthic strains. The line of descent separating the planktonic cluster from the benthic group gave a bootstrap value of $38.5 \%$ (Fig. 1).

Percentage similarities and the pairwise genetic distance matrix was produced by excluding gaps within the sequence alignment. Analysis of similarities produced when gaps were excluded from the alignment showed that the Nodularia genus was supported by similarities of greater than $96 \%$, whereas similarities to the outgroup Anabaena were less than $94 \%$ (data not shown). The $N$. spumigena cluster was supported by percentage similarities of greater than $98.7 \%$ and were up to $100 \%$ similar. Similarities within the $N$. harveyana/N. sphaerocarpa group were greater than $94.7 \%$. The percentage similarities and genetic distances support the Nodularia strains analysed in this study as a distinct genera from the Anabaena used as an outgroup in this study. 


\section{Evolutionary distribution of nodularin production throughout the genus Nodularia}

Production of nodularin was determined for all strains used in this study (Table 1). Since nodularin inhibits PP-2A at approximately the same potency as microcystin (Honkanen et al., 1990, 1991), the apparent concentration of nodularin was determined using a standard curve of PP-2A inhibition by standard concentrations of microcystin-LR (data not shown). All N. spumigena strains isolated from Australia and the Baltic Sea, excluding N. spumigena NSBL05, exhibited high levels of toxicity. All toxic Nodularia strains produced nodularin at levels of greater than

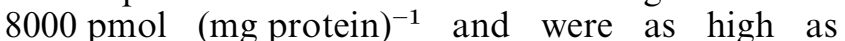
62000 pmol (mg protein) ${ }^{-1}$ for $N$. spumigena NSKR07 in comparison to Microcystis aeruginosa PCC 7806, which contained levels of microcystin at $3000 \mathrm{pmol}$ $(\mathrm{mg} \text { protein })^{-1}$. The detection limit of the standard curve was 33 pmol, and all strains below this limit were deemed non-toxic. The taxonomically controversial strain $N$. spumigena/ $N$. sphaerocarpa HKVV, $N$. spumigena strain PCC $73104^{\mathrm{T}}$ and N. spumigena strain UTEX-B2092 appeared not to produce toxin. All strains of $N$. harveyana and $N$. sphaerocarpa analysed showed no toxic effect, with the exception of $N$. harveyana PCC 7804, which appeared to be toxic by the protein phosphatase assay. Toxin data appeared to be consistent with previous toxin data (Bolch et al., 1999; Neilan et al., 1999) with the exception of PCC $73104^{\mathrm{T}}$, which was previously described as toxic (Neilan et al., 1999) but was found to be non-toxic in this study.

Toxic strains of $N$. spumigena that were examined by 16S rDNA sequencing were all members of a phylogenetically distinct group (Fig. 1). Biosynthesis of the hepatotoxin nodularin appears to be restricted to a single $N$. spumigena cluster. The non-toxic $N$. spumigena NSBL05 did not appear, however, to be phylogenetically different from other toxic bloom isolates (Fig. 1). This isolate is thought to contain a natural mutation or repressed nodularin biosynthesis (Bolch et al., 1999; M. C. Moffitt, unpublished data). Non-toxic strains N. spumigena PCC $73104^{\mathrm{T}}$ and $N$. spumigena UTEX-B2092 were in a separate group from the toxic cluster and appeared in the non-toxic $N$. harveyana/ $N$. sphaerocarpa polyphyletic group. All non-toxic strains defined taxonomically as $N$. harveyana and N. sphaerocarpa by classical methods (Komàrek et al., 1993) appeared to be delineated from the major toxic $N$. spumigena group in this study. Toxic strain N. harveyana PCC 7804 did, however, group with these non-toxic strains (Fig. 1). Toxin from this strain is thought to be a nodularin derivative, having a different HPLC retention time from that of nodularin found in toxic $N$. spumigena (Bolch et al., 1999).

According to the present $16 \mathrm{~S}$ rDNA sequence analysis, $N$. spumigena PCC $73104^{\mathrm{T}}$, the type strain for $N$. spumigena, and N. spumigena UTEX-B2092 did not phylogenetically cluster within the $N$. spumigena group. The ecological niche from which both strains were isolated was alkaline soil (Table 1), whereas strains within the $N$. spumigena phylogenetic cluster were isolated from planktonic algal bloom events. This clustering of $N$. spumigena PCC $73104^{\mathrm{T}}$ is consistent with results of $c p c$-IGS sequencing and RAPD-PCR performed by Bolch et al. (1999). The speciation of the non-toxic Nodularia strain HKVV is taxonomically incomplete and, as a result, has been confused in the past (Fujii et al., 1997; Lehtimäki et al., 1994). Analysis of $16 \mathrm{~S}$ rDNA in this study indicated that the non-toxic Baltic strain HKVV should be considered to be in the non-toxic group of $N$. sphaerocarpa and that this may be the correct speciation for this strain. Benthic strains of $N$. spumigena may also be reclassified within the group of benthic Nodularia. Since the type strain of $N$. spumigena is PCC $73104^{\mathrm{T}}$, reclassification of the toxicbloom-forming clade may be required.

Amongst the toxic cluster, there appears to be no delineation between strains isolated from geographically distinct regions and there appears to be a continuous cline of globality amongst toxic-bloomforming $N$. spumigena. Similar results were obtained in a previous study which analysed $c p c$-IGS sequences of Nodularia (Hayes \& Barker, 1997). Hayes \& Barker (1997) detected two distinct genotypes, one genotype which included Baltic strains BCNOD9427 and BY1 and the Canadian strain PCC $73104^{\mathrm{T}}$, and a second genotype containing Baltic and Australian isolates. Contrary to results of $c p c$-IGS RFLP analysis (Bolch et al., 1999; Hayes \& Barker, 1997), this study did not show that PCC $73104^{\mathrm{T}}$ was in the same cluster as BY1 and BCNOD9427. However, PCC 73104 ${ }^{\mathrm{T}}$ did cluster with the Baltic Sea strain HKVV. Recent findings resulting from $c p c$-IGS sequencing and RAPD-PCR were able to divide Australian strains into two main groups and show that they were distinct from overseas strains with the exception of strain BY1 (Bolch et al., 1999). The 16S rRNA phylogenetic tree created in this study was similar to the phylogenetic tree resulting from RAPD-PCR created by Bolch et al. (1999) with the toxic Baltic strain BY1 clustering with the toxic $N$. spumigena group and the overseas benthic $N$. harveyana and $N$. sphaerocarpa strains clustering distinct from planktonic and toxic $N$. spumigena Baltic Sea strains BCNOD9427 and HEM. New Zealand strain L575, which was not included in the Bolch et al. (1999) study, also clustered within the group of toxic $N$. spumigena. The combination of these data indicate that the phylogenetics of the small subunit RNA is reflected by the genomic evolution for this group of cyanobacteria. Alternatively, the structure of phycocyanin genes in this group may have experienced adaptive evolution with respect to the strain's ecological niche.

The clustering of toxic cyanobacterial strains within a single phylogenetically defined species as occurs in Nodularia has also been shown to occur within the genera Cylindrospermopsis and Anabaena (Beltran \& 


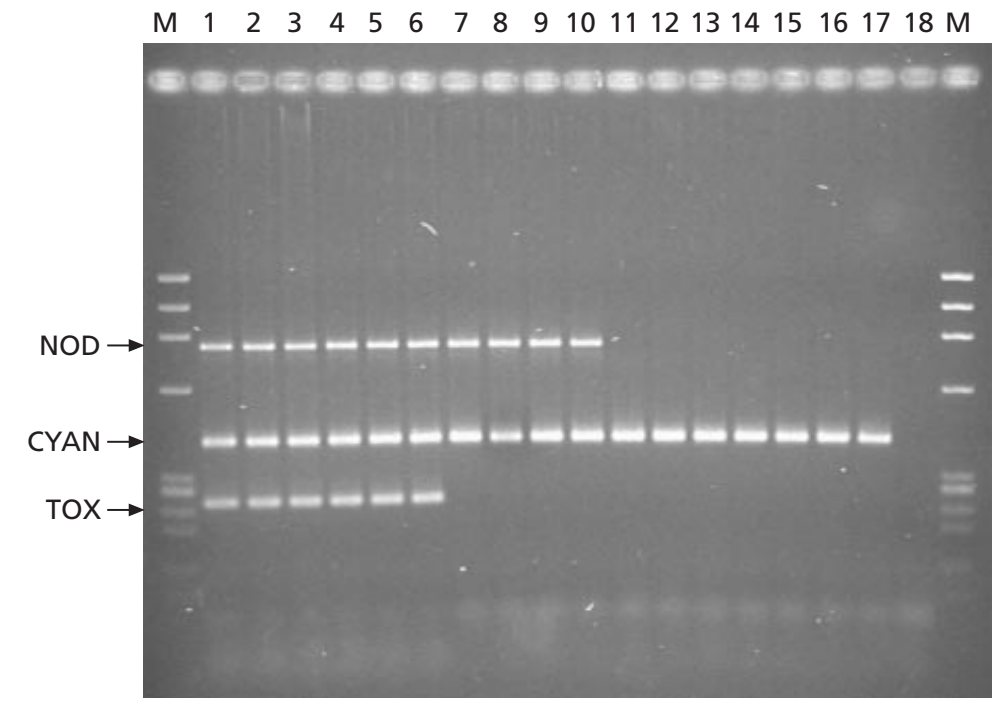

Fig. 2. Analysis of $16 \mathrm{~S}$ rRNA gene regions using cyanobacterial (Neilan et al., 1997) and Nodularia-specific oligonucleotide primers. Lanes 1-18 correspond to PCR fragments from strains $N$. spumigena $L 575$, HEM, BY1, NSOR10, NSBL05, NSPH05A14, $N$. spumigena/N. sphaerocarpa HKVV, N. sphaerocarpa CDAC 1966/93-1, N. harveyana PCC 7804, N. harveyana CDAC 1983/300, Anabaena cylindrica NIES19, Cylindrospermopsis raciborskii AWT205, Lyngbya AWT211, Aphanizomenon NIES81, Synechocystis PCC 6803, Microcystis aeruginosa PCC 7806, Anabaena PCC 7210 and no DNA (control), respectively. The marker lanes (M) contain PhiX174/Haelll. The cyanobacteriaspecific $16 \mathrm{~S}$ rDNA PCR amplified a $400 \mathrm{bp}$ fragment from all strains analysed (CYAN). The Nodularia genus-specific 16S rDNA PCR amplified a $780 \mathrm{bp}$ fragment from all Nodularia strains analysed in this study (NOD). The toxic $N$. spumigena-specific $16 \mathrm{~S}$ rDNA PCR amplified a $200 \mathrm{bp}$ fragment from all toxic planktonic bloom-forming Nodularia (TOX).

Neilan, 2000; L. Hardman, personal communication). In contrast, microcystin production within various genera of cyanobacteria does not appear to correlate with phylogeny according to 16S rRNA gene sequence analysis (Neilan et al., 1997). This suggests, in evolutionary terms, that the ability to produce nodularin has occurred recently and is confined to globally distributed strains of $N$. spumigena. It would also indicate that the prolific gene transfer observed in microcystin-producing cyanobacteria is not occurring between species of Nodularia (Neilan et al., 1999).

\section{Specific 16S rDNA probes for the detection of Nodularia}

Specific primers were designed from alignment of the $16 \mathrm{~S}$ rDNA sequences from all Nodularia analysed in this study with other members of order Nostocales (data not shown). A specific forward PCR primer (NS2) for the identification of members of the Nodularia genus was designed at position 705 of the Nodularia 16S rDNA sequence. The Nodularia-specific primer amplified members of the genus Nodularia only and was unable to amplify other members of the cyanobacteria (Cylindrospermopsis, Aphanizomenon and Anabaena) (Table 1), including members of the Nostocales, as well as strains from the genera Microcystis, Lyngbya and Synechocystis (Fig. 2). Within the group of Nodularia strains studied, the identification of toxic $N$. spumigena strains was possible with a specific primer (NTS) designed at position 1250. The corresponding PCR using this toxic Nodulariaspecific primer identified all nodularin-producing $N$. spumigena strains within the toxic-bloom-forming cluster and was unable to amplify non-toxic Nodularia strains and toxic strains from other genera (Fig. 2). In addition, these primers were able to amplify the
Nodularia-specific regions of the $16 \mathrm{~S}$ rRNA gene from DNA extracted from a bloom sample predominantly containing toxic N. spumigena (M. C. Moffitt \& B. A. Neilan, unpublished data). This primer, however, was unable to amplify DNA from the toxic strain $N$. harveyana PCC 7804.

This study was unable to analyse the phylogeny of the entire Nodularia morpho-genus, since the other four species are uncommon and not preserved or available as cultures. To accurately define the speciation of Nodularia as determined by the phylogenetic analysis of the 16S rDNA sequence, further analysis of representatives from all species of Nodularia is required. The Nodularia genus-specific primer presented here was useful for the amplification of a $780 \mathrm{bp}$ region of the 16S rRNA gene from members of the Nodularia genus as defined by the species sequenced in this study. There was no amplification of this region of the $16 \mathrm{~S}$ rRNA gene from other cyanobacteria tested. The toxic $N$. spumigena-specific primer was useful for the amplification of a $200 \mathrm{bp}$ region from the 16S rRNA gene of toxic strains analysed in this study. However, this primer did not amplify this region in the toxic strain $N$. harveyana PCC 7804, which is not a bloom-forming strain of $N$. spumigena. The toxic $N$. spumigena-specific primer was useful for the detection of cultured and uncultured toxic and planktonic strains. Currently, identification of a toxic Nodularia bloom event requires the microscopic analysis of cellular material and analysis of toxicity by expensive techniques such as HPLC, requiring high-density bloom material. This study reports the creation of Nodularia genus-specific and toxic-bloom-forming $N$. spumigena-specific $16 \mathrm{~S}$ rDNA oligonucleotide primers. These primers have the ability to detect low levels of Nodularia DNA in environmental samples, providing a quick and cheap 
method for determining the presence of potential bloom-forming Nodularia in predisposed waterways. Hence, this primer may become useful in the rapid detection of toxin-producing strains in environmental bloom events.

\section{ACKNOWLEDGEMENTS}

This work was financially supported by the Australian Research Council (ARC). M.C.M. is jointly supported by the ARC and the CRC for Water Quality and Treatment. B.A.N. is a fellow of the ARC.

\section{REFERENCES}

An, J. S. \& Carmichael, W. W. (1994). Use of a colorimetric protein phosphatase inhibition assay and enzyme linked immunosorbent assay for the study of microcystins and nodularins. Toxicon 32, 1495-1507.

Barker, G. L. A., Hayes, P. K., O'Mahony, S. L., Vacharapiyasophon, P. \& Walsby, A. E. (1999). A molecular and phenotypic analysis of Nodularia (Cyanobacteria) from the Baltic Sea. J Phycol 35, 931-937.

Beltran, E. C. \& Neilan, B. A. (2000). Geographical segregation in the neurotoxin-producing cyanobacterium Anabaena circinalis. Appl Environ Microbiol 66, 4468-4474.

Bolch, C. J. S., Blackburn, S. I., Neilan, B. A. \& Grewe, P. M. (1996). Genetic characterisation of strains of cyanobacteria using PCRRFLP of the $c p c \mathrm{BA}$ intergenic spacer and flanking regions. $J$ Phycol 32, 445-451.

Bolch, C. J. S., Orr, P. T., Jones, G. J. \& Blackburn, S. I. (1999). Genetic, morphological, and toxicological variation among globally distributed strains of Nodularia (cyanobacteria). $J$ Phycol 35, 339-355.

Carmichael, W. W. (1994). The toxins of cyanobacteria. Sci Am 270, 78-86.

Carmichael, W. W., Eschedor, J. T., Patterson, G. M. L. \& Moore, R. E. (1988). Toxicity and partial structure of a hepatotoxic peptide produced by the cyanobacterium Nodularia spumigena Mertens emend. L575 from New Zealand. Appl Environ Microbiol 54, 2257-2263.

Felsenstein, J. (1985). Confidence limits on phylogenies: an approach using the bootstrap. Evolution 39, 783-791.

Francis, G. (1878). Poisonous Australian lake. Nature 18, 11-12.

Fujii, K., Sivonen, K., Adachi, K., Noguchi, K., Shimizu, Y., Sano, H., Hirayama, K., Suzuki, M. \& Harada, K. (1997). Comparative study of toxic and non-toxic cyanobacterial products: a novel glycoside, suomilide, from non-toxic Nodularia spumigena HKVV. Tetrahedron Lett 38, 5529-5532.

Galat, D. L., Verdin, J. P. \& Sims, L. L. (1990). Large-scale patterns of Nodularia spumigena blooms in Pyramid Lake, Nevada, determined from Landsat imagery: 1972-1986. Hydrobiologia 197, 147-164.

Hawkins, P. R., Chandrasena, N. R., Jones, G. J., Humpage, A. R. \& Falconer, I. R. (1997). Isolation and toxicity of Cylindrospermopsis raciborskii from an ornamental lake. Toxicon $\mathbf{3 5}$, 341-346.

Hayes, P. K. \& Barker, G. L. A. (1997). Genetic diversity within Baltic Sea populations of Nodularia (Cyanobacteria). J Phycol 33, 919-923.

Heresztyn, T. \& Nicholson, B. C. (1997). Nodularin concentrations in Lakes Alexandrina and Albert, South Australia, during a bloom of the cyanobacterium (blue-green alga) Nodularia spumigena and degradation of the toxin. Environ Toxicol Water Quality 12, 273-282.

Honkanen, R. E., Zwiller, J., Moore, R. E., Daily, S. L., Khatra, B. S., Dukelow, M. \& Boynton, A. L. (1990). Characterization of microcystin-LR, a potent inhibitor of Type 1 and Type 2A protein phosphatases. J Biol Chem 265, 19401-19404.

Honkanen, R. E., Dukelow, M., Zwiller, J., Moore, R. E., Khatra, B. S. \& Boynton, A. L. (1991). Cyanobacterial nodularin is a potent inhibitor of Type 1 and Type 2 A protein phosphatases. Mol Pharmacol 40, 577-583.

Jones, G. J., Blackburn, S. I. \& Parker, N. S. (1994). A toxic bloom of Nodularia spumigena Mertens in Orielton Lagoon, Tasmania. Aust J Mar Freshw Res 45, 787-800.

Jukes, T. H. \& Cantor, C. R. (1969). Evolution of protein molecules. In Mammalian Protein Metabolism, vol. 3, pp. 21-132. Edited by H. N. Munro. New York: Academic Press.

Komàrek, J., Hübel, M., Hübel, H. \& Smarda, J. (1993). The Nodularia studies. 2. Taxonomy. Algol Stud 68, 1-25.

Lehtimäki, J., Sivonen, K., Luukkainen, R. \& Neimelä, S. I. (1994). The effects of incubation time, temperature, light, salinity and phosphorus on growth and hepatotoxin production by Nodularia strains. Arch Hydrobiol 130, 269-282.

Ligon, P. J., Meyer, K. G., Martin, J. A. \& Curtis, S. E. (1991). Nucleotide sequence of a 16S rRNA gene from Anabaena sp. strain PCC 7120. Nucleic Acids Res 19, 4553.

Nehring, S. (1993). Mortality of dogs associated with a mass development of Nodularia spumigena (Cyanophyceae) in a brackish lake at the German North Sea coast. J Plankton Res 15, 867-872.

Neilan, B. A., Jacobs, D. \& Goodman, A. E. (1995). Genetic diversity and phylogeny of toxic cyanobacteria determined by DNA polymorphisms within the phycocyanin locus. Appl Environ Microbiol 61, 3875-3883.

Neilan, B. A., Jacobs, D., Del Dot, T., Blackall, L. L., Hawkins, P. R., Cox, P. T. \& Goodman, A. E. (1997). rRNA sequences and evolutionary relationships among toxic and nontoxic cyanobacteria of the genus Microcystis. Int J Syst Bacteriol 47, 693-697.

Neilan, B. A., Dittmann, E., Rouhiainen, L., Bass, R. A., Schaub, V., Sivonen, K. \& Börner, T. (1999). Nonribosomal peptide synthesis and toxigenicity of Cyanobacteria. J Bacteriol 181, 4089-4097.

Nordin, R. N. \& Stein, J. R. (1980). Taxonomic revision of Nodularia (Cyanophyceae/Cyanobacteria). Can J Bot 58, 1211-1224.

Ohta, T., Sueoka, E., lida, N. \& 7 other authors (1994). Nodularin, a potent inhibitor of protein phosphatases 1 and $2 \mathrm{~A}$, is a new environmental carcinogen in male F344 rat liver. Cancer Res 54, 6402-6406

Patterson, G. M. L., Larsen, K. L. \& Moore, R. E. (1994). Bioactive natural products from blue-green algae. J Appl Phycol 6, 151-157.

Rippka, R. \& Herdman, M. (1992). Pasteur Culture Collection $(P C C)$ of Cyanobacterial Strains in Axenic Culture, vol. 1, Catalogue of Strains. Paris, France: Institut Pasteur.

Rippka, R., Deruelles, J., Waterbury, J. B., Herdman, M. \& Stanier, R. Y. (1979). Generic assignments, strain histories and properties of pure cultures of Cyanobacteria. J Gen Microbiol 111, 1-61.

Schleifer, K. H. \& Ludwig, W. (1989). Phylogenetic relationships among bacteria. In The Hierarchy of Life, pp. 103-117. Edited by B. Fernholm, K. Bremmer \& H. Joernvall. Amsterdam: Elsevier. 
Sivonen, K., Kononen, K., Carmichael, W. W., Dahlem, A. M., Rinehart, K. L., Kiviranta, J. \& Niemelä, S. I. (1989). Occurrence of the hepatotoxic cyanobacterium Nodularia spumigena in the Baltic Sea and structure of the toxin. Appl Environ Microbiol 55, 1990-1995.

Thompson, J. D., Higgins, D. G. \& Gibson, T. J. (1994). CLUSTAL w: improving the sensitivity of progressive multiple sequence alignment through sequence weighting, position specific gap penalties and weight matrix choice. Nucleic Acids Res 22, 4673-4680.

Woese, C. R. (1987). Bacterial evolution. Microbiol Rev 51, 221-271. 